\title{
Coordinating international interventions in complex settings. An analysis of the EU peace and state-building efforts in post-independence Kosovo
}

\author{
Chris van der Borgh, Puck le Roy \& Floor Zweerink
}

To cite this article: Chris van der Borgh, Puck le Roy \& Floor Zweerink (2018) Coordinating international interventions in complex settings. An analysis of the EU peace and statebuilding efforts in post-independence Kosovo, Peacebuilding, 6:3, 248-263, DOI: 10.1080/21647259.2018.1491280

To link to this article: https://doi.org/10.1080/21647259.2018.1491280
(c) 2018 The Author(s). Published by Informa UK Limited, trading as Taylor \& Francis Group
曲 Published online: 15 Aug 2018.

Submit your article to this journal

LII Article views: 262

View Crossmark data $\nearrow$ 


\title{
Coordinating international interventions in complex settings. An analysis of the EU peace and state-building efforts in post-independence Kosovo
}

\author{
Chris van der Borgh ${ }^{\mathrm{a}}$, Puck le Roy ${ }^{\mathrm{a}}$ and Floor Zweerink ${ }^{\mathrm{b}}$
}

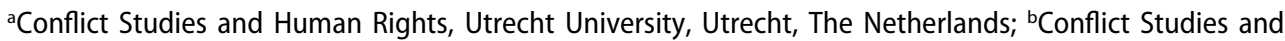
Human Rights, Utrecht University, Utrecht, The Netherlands

\begin{abstract}
This paper assesses coordination as a salient capability of international interventions in complex settings characterised by weak stakes, the dominance of political elites whose interest in reforms is questionable and multiple local and international stakeholders. It focuses on the challenge of integrating a range of national and international actors and multiple policy domains, assessing this operational capability in terms of a Whole-of-Society approach. Using the example of the EU's intervention in Kosovo through the mechanisms of the EULEX mission, and the EU-facilitated Dialogue between Serbia and Kosovo, the paper argues that the EU's impact in Kosovo was weakened by its limited ability to include and engage a broad range of local stakeholders. While a Whole-of-Society approach could address this weakness, the paper also argues that a better understanding of the context-specific opportunities and limitations placed on international organisations like the EU is needed.
\end{abstract}

\section{ARTICLE HISTORY}

Received 30 May 2018

Accepted 5 June 2018

\section{KEYWORDS}

Coordination; capabilities; international intervention; Kosovo; state building

\section{Introduction}

Over the past 20 years, the EU has transformed from an actor with limited leverage to a major player in Kosovo. Arguably, there is no other country where the EU plays a more central role in the processes of state building and stabilisation than in Kosovo. This paper discusses the EU's capabilities to coordinate with national and international stakeholders. Coordination is an important objective of most international actors, such as the UN, involved in state- and peacebuilding operations. It is, however, also widely acknowledged that coordination is often problematic. Roland Paris has noted that the call for improved coordination 'offers soothing simplicity in the face of disturbing complexity', since it often hides the 'disagreements and uncertainties about the means and ends of the entire enterprise'. 'Therefore, a realistic assessment of coordination and the scope of improvement should not only take into account

\footnotetext{
CONTACT Chris van der Borgh c.vanderborgh@uu.nl

'Paris, 'Understanding the "coordination problem" in postwar state-building', in Roland Paris and Timothy Sisk, The dilemmas of statebuilding. Confronting the contradictions of postwar peace operations (Abingdon, New York: Routledge, 2009), p. 53.

(c) 2018 The Author(s). Published by Informa UK Limited, trading as Taylor \& Francis Group

This is an Open Access article distributed under the terms of the Creative Commons Attribution-NonCommercial-NoDerivatives License (http://creativecommons.org/licenses/by-nc-nd/4.0/), which permits non-commercial re-use, distribution, and reproduction in any medium, provided the original work is properly cited, and is not altered, transformed, or built upon in any way.
} 
complexity, but depart from it. Complexity refers both to the context of intervention ${ }^{2}$ and to the peace operations themselves. ${ }^{3}$

This paper analyses international intervention in war-torn societies as essentially contested processes in which reaching consensus about ends and means appears to be extremely difficult and compromise is often flimsy at best. This has implications for the ideal of a Whole-of-Society (WoS) approach, which claims that better coordination will lead to better outcomes of interventions. For the capability to coordinate to be viable, there is a need for a deeper awareness of the contradictory interests and views about post-war societies and the tensions and contradictions between different reform processes. Therefore, the capability to coordinate should not be seen as a 'technique', but rather as a 'politics' of international actors.

The structure of this paper is as follows. It first reviews the academic discussion on coordination between national and international actors in general and the discussion about EU capabilities to coordinate in particular. It moves on with a short discussion of the years before Kosovo's independence, when the UN was the leading external actor, which already faced many of the problems that the EU would also be confronted with at a later stage. The next section focuses on the post-independence period when the EU started to play a prominent role in the process of state- and peacebuilding. The focus is on two of the most important EU interventions in Kosovo: the EULEX mission and the EU-facilitated Dialogue between Serbia and Kosovo. The paper closes with a reflection on the WoS approach.

\section{Forging and contesting capabilities}

The WoS approach seeks to encompass the complex dynamics of the conflict and postconflict environment through problematising not only the multi-actor environment but also the integration of different policies and peacebuilding actions across a broad spectrum of security needs. ${ }^{4}$ It refers to the EU's capabilities to synchronise their agendas with other international actors ('international coordination') and with local stakeholders, including warring parties, governments and civil society (inclusivity). While the need for international coordination has been stressed by international actors over the past decades, inclusivity is an emerging norm within international policy processes. ${ }^{5}$ This paper deals with the capability to coordinate with international- and national-level actors.

A capability is about the ability and capacity to achieve objectives in relation to the overall mission of an international organisation or any other actor that is able to make policy. It has to be understood in relation to expectations and ambitions with regard to stated (policy) goals. The higher the expectations and ambitions regarding the goals, the

2J. Goodhand and D. Hulme, 'From Wars to Complex Political Emergencies: Understanding Conflict and Peace-Building in the New World Disorder', Third World Quarterly, 20, no. 1 (1999), 15-16.

${ }^{3}$ C. Clement and A. C. Smith, eds., Managing Complexity: Political and Managerial Challenges in United Nations Peace Operations (New York: International Peace Institute, July 2009), https://www.ipinst.org/wp-content/uploads/publica tions/complexity_1.pdf; C.T. Hunt, UN Peace Operations and International Policing. Negotiating Complexity, Assessing Impact and Learning To Learn (Abingdon, New York: Routledge, 2015).

${ }^{4} \mathrm{M}$. Martin, V. Bojicic-Dzelilovic, C. van der Borgh and G. Frerks, Theoretical and Methodological Framework (London: London School of Economics and Political Science and Utrecht: Utrecht University, 2016), 14.

${ }^{5} \mathrm{~T}$. Donais and E. McCandless, 'International peace building and the emerging inclusivity norm, Third World Quarterly 38 , no. 2 (2017): 291-310. 
greater the capabilities needed to realise these. ${ }^{6}$ With the growing number of peace operations and their more complex mandates after the cold war, the question of coordination has gained importance and is considered a capability in its own right. ${ }^{7}$ This is also the case for the EU, whose expectations regarding inclusivity and comprehensiveness are quite high and form a leitmotif in its policies. The Comprehensive Approach to security is the way the EU seeks to operationalise these ideas. ${ }^{8}$ It is, however, widely recognised that implementation raises a range of challenges 'at the politico-strategic level, at the level of operational and policy planning and in day-to-day implementation'?

In their framework to analyse capabilities, Whitman and Wolff emphasise that capabilities should be understood in their respective contexts (the context-capability nexus). ${ }^{10}$ The authors make a distinction between four types of context: local, national, regional and global and the need to deal with different actor constellations and challenges at each of these levels. ${ }^{11}$ Furthermore, three types of capabilities are identified that the EU needs in order to be effective: the capability to act, to fund and to coordinate and cooperate. ${ }^{12}$ With regard to coordination and cooperation, the authors focus on the capability to coordinate between international actors, while emphasising the need to take into account local actors and to 'determine the relevant players and analyse in detail their interests and capabilities and on the basis of this begin to build as broad a coalition as possible in support of an outcome-oriented process'. ${ }^{13}$ This implies that, in order to be effective, coordination and cooperation with other actors - aligning different interests and agendas - are key to international intervention. In other words, most actions of international agents require the inputs, consent or agreement of a range of other actors - both local and international. The possibilities and limitations to do so depend on the relevant contexts.

In the academic literature, calls for inclusiveness and comprehensiveness of international peace- and state-building policies have been critically examined. ${ }^{14}$ Discussing the efforts of international actors to coordinate their policies, Paris warns against seeing coordination as a 'technique' to overcome the often disappointing outcomes of peace and state-building interventions. ${ }^{15}$ The concept suggests a pre-existing consensus and insufficiently takes into account strategic disagreements over state-building, the political roles played by international interveners and the complexities of local societies and power dynamics (ibid). The EU is not unaware of this and proclaims to use its 'soft

\footnotetext{
${ }^{6}$ Martin, Theoretical and Methodological Framework.

${ }^{7}$ R. Whitman and S. Wolff, eds., The European Union as a Global Conflict Manager (Abingdon, New York: Routledge, 2012): 11.

${ }^{8} \mathrm{C}$. Gebhard and P. Norheim-Martinsen, 'Making Sense of EU Comprehensive Security towards Conceptual and Analytical Clarity', European Security, 20, no. 2 (2011): 221.

${ }^{9}$ lbid.,221.

${ }^{10}$ Whitman and Wolff, The European Union, 213.

${ }^{11}$ Ibid, 14-17.

${ }^{12} \mathrm{lbid}, 11$.

${ }^{13}$ Ibid, 218.

${ }^{14} \mathrm{C}$. Castillejo, Dilemmas and experiences of international support for inclusive peacebuilding, Report (Oslo: Noref, 2017). file:///C:/Users/Chris/Downloads/Castillejo_Dilemmas\%20and\%20experiences\%20of\%20international\%20support\%20for\%20inclusive\%20peacebuilding_Oct2017_final.pdf; V. Dudouet and S. Lundström, Post-war Political Settlements. From Participatory Transition Process to Inclusive State-building and Governance, Research Report (Berlin: Berghof Foundation, 2016).

${ }^{15}$ Paris, 'Understanding', 58-60.
} 
power' through non-coercive measures aimed at gaining the consent of other stakeholders in policy implementation. ${ }^{16}$ However, interventions are fundamentally contested processes in which the interests of international, national and subnational actors often widely differ. ${ }^{17}$ Hence, the different actors involved in the interventions are not necessarily 'coordinating', but rather interacting strategically with each other. According to Barnett and Zürcher, the most likely outcome is not consent of local actors, but a 'compromise' between the different stakeholders that only superficially reflects the agendas of international actors. ${ }^{18}$

These sobering accounts of the possibilities of coordination, comprehensiveness and inclusion (in Kosovo and beyond) raise the question to what outcomes coordination and negotiations between different national and international elites lead. We do not assume that the interests of different stakeholders are necessarily incompatible, or fixed, but rather follow Colebatch's view of policy as structured interaction. ${ }^{19}$ In this view, policy should not simply be seen as the pursuit of 'shared goals', but also as the more difficult task of negotiating and constructing a basis for collective action among participants with quite diverse views on the nature of the task. $^{20}$ The analysis of intervention requires a reconstruction of the interactions between the relevant players in a given 'policy area' or 'policy arena'. These can be players that are directly involved, but also stakeholders that would like to be included. $^{21}$ Zooming in on these relations provides more detailed insight in the ways in which capabilities develop, adapt, grow or erode in complex and largely unpredictable processes.

In the sections below, we analyse the strategic manoeuvring of the EU in Kosovo, focusing on two of its most important interventions there: the EU mission and the EU-facilitated Dialogue. These sections are based on a more elaborate analysis, which traced these interventions, focusing on the interactions between actors, and the resulting adaptation in (international) policies. ${ }^{22}$ In our analysis, we made a distinction between policy design, policy implementation and policy change and adaptation. $^{23}$ For each stage, the relevant actions of the EU were identified, the relevant interactions with other stakeholders, and the outcomes of policy measures as assessed by different stakeholders. ${ }^{24}$ In that process, local and international interests and agendas are not separate and fixed but influence each other, and

\footnotetext{
${ }^{16} \mathrm{~K}$. Nielsen, 'EU Soft Power and the Capability-expectations Gap', Journal of Contemporary European Research, 9, no. 5 (2013): 723-39.

${ }^{17}$ M. Barnett and C. Zürcher 'The Peacebuilders Contract: How External State-Building Reinforces Weak Statehood', in Paris and Sisk, The dilemmas of state-building (2009), 13-52; A. de Waal, 'Mission Without End? Peacekeeping in the Political Marketplace', in International Affairs, 85, no. 1 (2009): 99-113.

${ }^{18}$ Barnett and Zürcher, 'The peacebuilders contract'.

${ }^{19}$ H. Colebatch, Policy (Maidenhead: Open University Press/McGraw-Hill Education, 2009), 26.

${ }^{20}$ Ibid.

${ }^{21}$ Ibid., 4.

${ }^{22}$ C. van der Borgh, P. le Roy, and F. Zweerink, EU peacebuilding capabilities in Kosovo after 2008: an analysis of EULEX and the EU-facilitated Belgrade-Pristina Dialogue (Utrecht: Utrecht University, 2017), http://www.woscap.eu/docu ments/131298403/131299900/Kosovo+report_PU+\%285\%29.pdf/3f0fb0f7-e81c-4e42-bdee-c43efabfafed. The research is based on a literature review and focuses on the interactions between national and international elites. In addition, in May, June and September 2016, 12 interviews were held in the Netherlands, Brussels and Kosovo with (former) staff of international organisations, local NGO leaders (in Pristina and Mitrovica) and local researchers and journalists.

${ }^{23}$ Martin, Methodological Framework, 35.

${ }^{24}$ lbid.
} 
they are 'interlocked'. ${ }^{25}$ Thus, instead of looking for capability as something dichotomous that external interveners either have or have not, the focus of this paper is on the social processes in which capabilities emerge and erode in (often changing) national and local contexts.

\section{UNMIK's heritage and status issues}

With the suspension of NATO's bombing campaign, on 10 June 1999, the UN Security Council passed Resolution 1244, which announced the Council's decision to replace the Federal Republic of Yugoslavia's (FRY) authorities with the deployment of international civil and security presences in Kosovo: the United Nations Interim Administration Mission in Kosovo (UNMIK) and the NATO led Kosovo Force (KFOR). Although Resolution 1244 recognised FRY's sovereignty over Kosovo, UNMIK - an international administration - became the 'de facto' government. While UNMIK was supposed to promote 'meaningful self-governance', the international community postponed the decision on Kosovo's status, which remained a bone of contention between the Serbian minority in Kosovo and the majority Kosovo Albanians. ${ }^{26}$

The immediate post-intervention period in Kosovo (between 1999 and 2008) was characterised by multiple conflicts about Kosovo's status and legitimate governance between local Kosovo-Albanian actors (the Democratic League of Kosovo and the Kosovo Liberation Army), as well as between Serbian and Kosovar groups. ${ }^{27}$ In this context, UNMIK faced numerous dilemmas to deal with local actors and to foster local ownership. ${ }^{28}$ The international administration of UNMIK was reluctant to take the upper hand and preferred to hide behind a discourse of local ownership. ${ }^{29}$ Narten argues that UNMIK chose to work with 'the still powerful, former warring parties that were also engaged in postwar crime activities' and that it 'missed the critical point for a well-balanced identification and strengthening of local partners through a consistent transfer of powers, and by not setting transparent, fair, and realistically achievable benchmarks with clearly defined indicators of achievement for local counterparts' ${ }^{30}$

Also, there were multiple coordination problems between international actors. With the chaotic organisation of the international community in Bosnia still fresh in everyone's mind, attempts were made to bring more structure into the civil and administrative mission in Kosovo. It was therefore decided to opt for a 'pillar model', with the European Union and the Organisation for Security and Cooperation in Europe (OSCE) reporting to UNMIK. While this was generally regarded as a step forward, it did not prevent 'turf wars' between and within these organisations. King and Mason point to UNMIK's failed attempts to coordinate the activities of the various international

\footnotetext{
${ }^{25}$ This is a variation on Long and Van der Ploeg's concept of interlocking projects. See N. Long and van der Ploeg, 'Heterogeneity, actor and structure: Towards a reconstitution of the concept of structure', in Booth, D. Rethinking Social Development: Theory, Research and Practice, London: Longman, 1994), 62-89.

${ }^{26} \mathrm{C}$. van der Borgh, 'Resisting International State Building in Kosovo', Problems of Post-Communism, 59, no. 2 (2012): $31-42$.

${ }^{27}$ Ibid.

${ }^{28}$ S. Chesterman You, The People: The United Nations, Transitional Administration, and State-Building (Oxford, Oxford University Press, 2004); J. Narten, 'Dilemmas of promoting "local ownership": the case of postwar Kosovo, in Paris and Sisk, The Dilemmas of Statebuilding, 252-83.

${ }^{29}$ Chesterman, You, the People.

${ }^{30}$ Narten, 'Dilemmas of promoting', 271, 276.
} 
organisations, and the fact that UNMIK was serving too many masters, thereby causing a lack of unity. ${ }^{31}$ Indeed, the early years of international intervention in Kosovo showed that consensus about Kosovo's political future and the transitional administration were lacking, which deeply hampered UNMIK's efforts to coordinate. Faced with this problematic political reality, UNMIK delayed transferring power to local institutions and avoided to engage in a discussion on Kosovo's status between 1999 and 2002. ${ }^{32}$ This made UNMIK widely unpopular among the Kosovo Albanians, who scornfully referred to the UN mission as 'anmik', which means 'enemy' in Kosovo Albanian. ${ }^{33}$

The absence of a clear road map about the future status of Kosovo 'posed a virtually insurmountable obstacle in the efforts of the international administration to bring lasting peace and stability'. ${ }^{34}$ By the year of 2004, events on the ground, including the anti-Serbian riots in March, forced the international community to put the issue of Kosovo's status back on its agenda. In February 2007, Ahtisaari presented his draft 'Comprehensive Status Proposal' (CSP) to both Belgrade and Pristina. ${ }^{35}$ The CSP recommended 'conditional independence supervised by the international community, [...] that reintegration into Serbia was not viable, and continued international administration was not sustainable'. ${ }^{36}$ The Serbian side rejected the conclusion of the Ahtisaari report. The Serbs living in Kosovo were also very much opposed to the Ahtisaari plan, as they feared Kosovo's independence would ultimately lead to Albanian domination in Kosovo and would result in their loss of the practical and financial advantages of the Serbian state presence in Kosovo. ${ }^{37}$

The EU and the USA initially hoped the UN Security Council would endorse Ahtisaari's CSP with a new resolution that would supersede Resolution 1244, even though Serbia had rejected the draft. When it became clear that the Ahtisaari plan did not receive enough support within the Security Council due to the expected negative veto of Russia and China, ${ }^{38}$ the EU unable to define her position towards Kosovo and aware that inaction could damage her reputation, began to consider bypassing the Security Council. Finally, the USA, together with a group of EU Member States, facilitated Kosovo's unilateral declaration of independence, delivered by Kosovo's political representatives on 17 February 2008. ${ }^{39}$ The declaration specifically mentioned the Ahtisaari plan, and Kosovo pledged it would fully implement it. ${ }^{40}$ In 2008, the International Civilian Office was created to supervise Kosovo's independence. It was headed by Mr Pieter Feith, who had already been appointed the EU Special Representative (EUSR) in Kosovo. ${ }^{41}$

\footnotetext{
${ }^{31}$ I. King and W. Mason, Peace at Any Price. How the World Failed Kosovo (London, Hurst and Company, 2006).

${ }^{32} \mathrm{G}$. Visoka, 'International Governance and Local Resistance in Kosovo: the Thin Line between Ethical, Emancipatory and Exclusionary Politics', Irish Studies in International Affairs, 22 (2011), 99-125.

${ }^{33}$ W. Koeth, 'State Building Without a State: The EU's Dilemma in Defining its Relations With Kosovo', European Foreign Affairs Review, 15 (2010): 227-47.

${ }^{34}$ Yannis, A, 'The UN as Government in Kosovo', Global Governance, 10, no. 1 (2004): 75; Koeth, 'State Building', 231.

${ }^{35}$ Ahtisaari was assisted by two EU officials from both the Council of the European Union and the European Commission.

${ }^{36}$ Koeth, 'State Building Without a State', 232.

${ }^{37}$ F. Bieber, The Serbia-Kosovo Agreements: An EU Success Story? Review of Central and East European Law, 40 (2015), 285-319.

${ }^{38}$ Visoka, 'International Governance'.

${ }^{39}$ Koeth, 'State Building Without a State'.

${ }^{40}$ F. T. Bislimi, 'International Statebuilding in Kosovo: The Shifting Trend in the Level of US-EU Involvement', The Western Balkans Policy Review, 2, no. 2 (2012): 48-72.

${ }^{41}$ International Civilian Office, State Building and Exit. The International Civilian Office and Kosovo's Supervised Independence 2008-2012 (Pristina: ICO, December 2012), 57.
} 
After 2008, the status issue was still far from settled and continued to plague efforts to bring stability and peace to the region and to build a new Kosovar state. Serbia was not willing to recognise Kosovo's independence and continued its influence in Kosovo by supporting Serbian 'parallel' governance structures. By September 2016, two of the permanent five members of the Security Council - Russia and China - did not recognise Kosovo (111 countries had recognised Kosovo as an independent state). ${ }^{42}$ Moreover, 5 of the 27 members of the EU - Spain, Slovakia, Greece, Romania and Cyprus - had not recognised Kosovo's independence either, leading to serious challenges for the EU in dealing with the state. This continuing international disagreement about Kosovo's status continued to hamper the deployment of the international community.

Thus, over the past two decades, a broad range of international organisations have been involved in the management and resolution of the conflict on and in Kosovo. After Kosovo's declaration of independence, the EU stepped up its presence in Kosovo, inheriting a series of structural problems that were not easy to resolve. Kosovo's status was and remained a point of contention between Kosovo and Serbia, within the EU and at international level. The state-building process of Kosovo was seriously hampered by the lack of consensus about Kosovo's status, as well as the high levels of corruption in the country.

\section{EU interventions in Kosovo after 2008}

Over the past 20 years, the influence of the EU in Kosovo 'has been expanding gradually into the political, judicial, economic and security spheres'. ${ }^{43}$ In the weeks following 10 June 1999, when UNMIK was deployed in Kosovo, the EU agreed to become a stakeholder in the UN mission through financing 'Pillar IV' or 'the EU Pillar' of UNMIK. Completely financed by the European Commission, the EU Pillar, together with the newly established European Agency for Reconstruction and the EU Monitoring Mission of the Council of the EU, made up the EU presence in Kosovo. ${ }^{44}$ It was, however, after Kosovo's declaration of independence on 17 February 2008 that the EU took over the most important tasks of Kosovo's rule of law reform. ${ }^{45}$

In this section, two of the most important interventions of the EU will be discussed into more detail: the EULEX mission and the EU-facilitated Dialogue between Serbia and Kosovo. In both, the challenges to coordinate a range of actors were of great importance but were dealt with in different ways. The number of EU interventions and engagements with Kosovo was, however, broader. Particularly important was the Stabilisation and Association Process, which was developed as a common framework for relations with the Western Balkans up to their accession to the European Union. The Stabilisation and Association Agreements (SAA's) served as an important carrot during the dialogue process between Kosovo and Serbia and the SAA with Kosovo

\footnotetext{
${ }^{42}$ See Republic of Kosovo Ministry of Foreign Affairs. (2016). International recognitions of the Republic of Kosovo. Retrieved from Republic of Kosovo Ministry of Foreign Affairs, http://www.mfa-ks.net/?page=2,224.

${ }^{43}$ Krasniqui, G., 2015, 'The EU's Relations with Kosovo - Achievements, Limits, Challenges', European Futures: http:// www.europeanfutures.ed.ac.uk/article-2482.

${ }^{44}$ Koeth, 'State Building Without a State'.

${ }^{45}$ Bislimi, 'International Statebuilding in Kosovo'.
} 
entered into force on 1 April 2016. ${ }^{46}$ In addition, Kosovo has been one of the most important recipients of European technical and financial cooperation, which was, inter alia, used to fund activities of institution building and socio-economic development. ${ }^{47}$

\section{EULEX - compromises, compromises, compromises}

Established in 2008, the objectives of the EULEX include the support of the police and judiciary, border management and tackling of corruption and organised crime. ${ }^{48} \mathrm{With}$ an annual budget of around 76 million Euros ${ }^{49}$ in 2016, it is the most expensive mission ever executed by the European Union. ${ }^{50}$ On top of that, its partly executive mandate in addition to its 'strengthening' mandate - also set this EU mission apart from other civilian missions deployed under the CSDP in the Western Balkans. ${ }^{51}$ EULEX faced enormous challenges in terms of its capability to coordinate, and the Mission has been extensively criticised, in academic and policy literatures, in formal evaluations and by political leaders in Kosovo and Serbia (albeit for different reasons). ${ }^{52}$

As to the reasons for EULEX's relatively poor performance, there is little doubt that at all levels (local, national, regional and international), the mission encountered serious challenges that influenced its performance. However, the report of the European Court of Accountants published in 2012 emphasised that these 'specific circumstances' could only partly be held responsible for the disappointing results of the EULEX mission. ${ }^{53}$ This is a fair point, since a number of organisational problems were responsible for the relatively poor results. For example, EULEX faced problems to contract capable staff and in terms of its administration and its communication strategy. Furthermore, the fact that a civilian mission was initially led by a military staff member was questioned by several (former) staff members of EULEX. ${ }^{54}$ In addition, the objective of EULEX to address the rule of law in almost all its dimensions may well have been too ambitious.

\footnotetext{
${ }^{46} \mathrm{P}$. van Elsuwege, 'Legal Creativity in EU External Relations. The Stabilisation and Association Agreement between Kosovo and the EU', European Foreign Affairs Review 22, no. 3 (2017): 393-410. A key development in the framework for the EU's relationship with the candidate and potential candidate countries of the Western Balkans has been visa liberalisation.

${ }^{47}$ Van der Borgh, 'EU peacebuilding capabilities'.

${ }^{48}$ European Court of Auditors, European Union Assistance to Kosovo Related to the Rule of Law (Luxembourg: European Court of Auditors, 2012), 11. See for the mission statement Joint Action 2008/124/CFSP.

${ }^{49}$ EULEX (n.d.) 'Basic Facts', http://www.eulex-kosovo.eu/eul/repository/docs/AE20160531_Fact_Sheet_1.2.pdf (accessed June 2, 2016).

${ }^{50} \mathrm{~S}$. Laudes and F. Sánchez Andrada, 'EULEX: A mission in need of reform and with no end in sight', (Real Instituto Elcano Royal Institute, 2015), http://www.realinstitutoelcano.org/wps/portal/web/rielcano_en/contenido?WCM_ GLOBAL_CONTEXT=/elcano/elcano_es/zonas_es/europa/ari41-2015-Ilaudes-sanchezandrada-eulex-mission-needreform-no-end-in-sight .

${ }^{51} \mathrm{M}$. Spernbauer EULEX Kosovo - Mandate, structure and implementation: Essential clarifications for an unprecedented EU mission (Brussels: CLEER, 2010).

${ }^{52}$ See S. Bajrami, 'The Rule of Law in Kosovo: Mission impossible?' (Balkan Insight, 2011), http://www.balkaninsight.com/ en/article/the-rule-of-law-in-kosovo-mission-impossible; T. Cierco and L. Reis, 'EULEX's impact on the Rule of Law in Kosovo', Revista de Ciencia Politicia, 34, no. 3 (2014): 645-63; European Court of Auditors, European Union Assistance; Laudes and Sanchez, 'Eulex: A mission in need of reform'; A. Radin 'Analysis of current events: "towards the rule of law in Kosovo: EULEX should go"', Nationalities Papers, 42, no. 2 (2014): 181-94. See for a more positive evaluation R. Zupančič, N. Pejič, B. Grilj, and A. Peen Rodt, 'The European Union Rule of Law Mission in Kosovo: An Effective Conflict Prevention and Peace-Building Mission?', Journal of Balkan and Near Eastern Studies (2017) http://www.tandfonline. com/doi/pdf/10.1080/19448953.2017.1407539?needAccess=true.

${ }^{53}$ European Court of Auditors, European Union Assistance.

${ }^{54}$ Author's interview with Pieter Feith, Dutch diplomat and former EU Special Representative and International Civilian Representative in Kosovo, 20 June 2016, The Hague.
} 
But although in the given circumstances EULEX could have done more, the complexities of the interconnected local, national and international contexts should not be underestimated. EULEX needed to deal at all these levels with actors that disagreed about the future of Kosovo and the role that EULEX should play.

At the international level, EULEX faced serious coordination problems. Within the EU, there was no consensus about the status of Kosovo, and the head of the EULEX mission had to manage the diverse interests among the 28 member states (with their representations in the political and security committee). In the words of the former EUSR Pieter Feith: 'a big part of my job consisted of compromising, compromising, compromising' ${ }^{55}$ When the EU started to develop EULEX, it assumed that the mandate under which the UN had worked (UNSCR 1244) would be changed. However, the continuing ambiguity and controversy about the status of Kosovo, both at the international level and within the EU, led to renegotiations about the deployment of EULEX and eventually to a 'handicapped'56 EULEX mission that declared itself to be 'status neutral'. This negatively influenced the effectiveness of EULEX's intervention. These early years of the EULEX mission show that a low capability to coordinate the international position on Kosovo's status (also within the EU) seriously hampers the international capacity to act.

The EULEX mission also encountered serious obstacles in its interactions with national elites. Barnett and Zürcher claim that the counterparts of governance programmes often do not have a genuine interest in the proposed reforms, proved - at least in part - true for the case of Kosovo. While EULEX both aimed at strengthening the Kosovar judicial sector and to take the necessary measures (among others through its executive mandate) to stop corruption, several reports pointed at their problematic implementation. ${ }^{57}$ The Marty Report mentioned corruption as a major problem, claiming that the political power of Kosovar elites that allegedly had connections with organised crime, counted on the 'de facto' support of the EU and the USA. ${ }^{58}$ The European Court of Auditors (ECA) report shared that view and quoting OSCE studies about the high risk of Kosovo becoming (or even of actually already being) a 'captured state' ${ }^{59}$ It also noted that 'the Kosovo authorities have given a low priority to anticorruption activities', and it explicitly questioned the political will of the political elites to implement new reforms. ${ }^{60}$ Some of the concerns expressed by ECA in the 2012 report were also mentioned in the 'Jacqué Report'. ${ }^{61}$ While this report focuses on the allegations of corruption within EULEX and the treatment of alleged whistle-blowers, part of the report discusses the more general implementation of the mandate by EULEX, concluding that 'in its current state Kosovo's judicial system does not seem

\footnotetext{
${ }^{55}$ Ibid.

${ }^{56} \mathrm{~L}$. Greicevci, L. 'EU actorness in international affairs: The case of EULEX mission in Kosovo', in Perspectives on European Politics and Society, 12, no. 3 (2011): 283-303.

${ }^{57}$ Barnet and Zürcher, 'The peacebuilders contract'.

${ }^{58}$ Tolksdorf, D., 2013, EU and U.S. cooperation in rule of law assistance in Kosovo. Paper prepared for presentation at the 8th Pan-European Conference on International Relations, 18-22 September 2013. Warsaw, 17.

${ }^{59}$ European Court of Auditors, European Union Assistance, 22.

${ }^{60}$ Ibid., 23-24.

${ }^{61}$ Jacqué, J.-P, Review of the Eulex Kosovo Mission's Implementation of the Mandate with a particular focus on the handling of the recent allegations. Report to the attention of High Representative / Vice President of the European Commission Ms Federica Mogherini (2015).
} 
to be capable of meeting the challenges of corruption and the organized crime associated with it'. 62

Former EU staff recognised the problem of political elites' involvement in organised crime and corruption. Former EUSR Peter Feith argued that EULEX had insufficiently been able to address this, arguing that EULEX also lacked a clear vision of how to achieve this. In this regard, the political support of key EU member states - like Germany and the UK - as well as the USA, to take tougher measures was lacking, since a tougher stance would have come at the cost of stability in Kosovo. ${ }^{63}$ This critique was also voiced by Capussela, who summarises the attitude of the West since 1999 as preferring 'to appease, rather than confront, Kosovo's leadership' ${ }^{64}$ In order to implement its 'reform agenda', EULEX (and the EU in general) chose to cooperate with these same political elites that seemed not sincerely interested in it.

It is also striking that, even though EULEX claimed to aim for a 'locally owned' rule of law mission, consultation of Kosovar civil society initially was rather limited. An evaluation of European Peacebuilding Liaison Office (EPLO) about the first years of EULEX concluded that while there were interactions with civil society representatives, these had not been formalised yet and mostly consisted of providing information. ${ }^{65}$ The same report mentions that a number of civil society organisations were very critical about EULEX' executive powers and its 'status neutrality'. For example, the CSO Lëvizja Vetëvendosje (Self-Determination; which would later become a political party) opposed the presence of EULEX (and of UNMIK). More generally, the report pointed at the contradiction that it seems that EULEX faces a very delicate situation in which people expect to see concrete results in terms of improvements in the Kosovar rule of law institutions whilst at the same time being very sensitive to perceived infringements on Kosovo's national sovereignty'. ${ }^{66}$ At a later stage, the interaction of EULEX with civil society representatives increased, but many Kosovars remained highly critical about EULEX. ${ }^{67}$ Moreover, there were strong differences in the expectations of KosovoSerbian and Kosovo Albanian citizens regarding EULEX (ibid). Overall, the critique on EULEX dominated. As an international NGO staff member noted: 'In the fall of last year (2015) I participated in a civil society consultation in Brussels organized by EPLO. It was on the future of EULEX, and people from the Kosovo civil society participated. EULEX is incredibly, astonishingly unpopular. That was the feedback from Kosovo civil society' ${ }^{6}$

In addition, it proved almost impossible for EULEX to work in the North of Kosovo. Supported by Belgrade, the Serbs in the northern parts of Kosovo had, for quite a long time, refused to recognise EULEX, which downgraded the capacity of EULEX in the North - an extremely difficult starting point for the mission. However, Brussels had been reluctant to deploy EULEX in the North. ${ }^{69}$ The effort of the Kosovar government

\footnotetext{
${ }^{62}$ Ibid., 12.

${ }^{63}$ Author's interview with Pieter Feith, 20 June 2016, The Hague.

${ }^{64} \mathrm{~A}$. L. Capussela, 'The West's state-building policy in Kosovo requires a radical overhaul', http://blogs.lse.ac.uk/ europpblog/2016/05/05/the-wests-deluded-and-ineffective-policy-in-kosovo-should-change/.

${ }^{65} \mathrm{M}$. Palm, Accountability and Effectiveness of CSDP Missions: The Role of Civil Society. The Cases of EULEX (Kosovo) and EUPOL COPPS (Palestinian Territories) (Brussels: EPLO, no date).

${ }^{66}$ Ibid., 11.

${ }^{67}$ Mahr, E., 2017, 'Local contestation against the European Union Rule of Law Mission in Kosovo', Contemporary Security Policy, http://www.tandfonline.com/doi/full/10.1080/13523260.2017.1407060.

${ }^{68}$ Author's interview with Michael Warren, Pax, the Netherlands, Utrecht, May 2016.
} 
to control the North led to new violent clashes during the summer of $2011 .^{70}$ As a result, EULEX officials faced frequent roadblocks and threats and KFOR had to be deployed to re-establish security. ${ }^{71}$ As will be discussed in the next section, the continuing problems in the North were the reasons for the EU to demand Kosovo and Serbia to start a dialogue about normalisation of their relations in March 2011. Again, in such a complex situation, the possibilities of EULEX to coordinate or collaborate with local actors were quite limited. It may be argued that EULEX could have done more and better in the North, but this would not be easy given the fierce opposition from Belgrade.

All in all, the experience of EULEX shows that it proved extremely difficult to coordinate the interests and agendas at the international, national and local levels. The interests and preferences of the different stakeholders that EULEX had to deal with (especially the Kosovar and Serbian governments) were often contradictory and highly sensitive since in most cases they related in one way or the other to the status issue. In this regard, Capussela argued that the main problem was not a lack of coordination with national elites, but an 'overdose' of it, and that a firmer position of the international community vis-à-vis national elites would be needed to overcome the challenges of corruption: 'Real change is only possible in Kosovo if the current leadership's political, economic, and military power is credibly challenged'. ${ }^{72}$ This would imply a stricter and stronger role of international interveners, which would not only be resisted by national elites, but probably also by a number of civil society groups. In this regard, EULEX strongly relied on cooperation with national political leaders. That choice was even more visible in the Dialogue, which will be discussed in the next section.

\section{The EU-facilitated Dialogue - A European method?}

The aim of the EU-facilitated Dialogue between Belgrade and Pristina was to normalise the relations between the two sides, to promote cooperation, to help them achieve progress on their path to EU membership and to improve the lives of the people of Serbia and Kosovo. ${ }^{73}$ The reason to initiate the Dialogue was the ongoing tensions between Kosovo and Serbia, which hampered the deployment of the EULEX mission (particularly in the North of Kosovo). The EU used its political leverage to bring the two parties to the table (despite the reluctance of the two sides), making the normalisation of the relations between Kosovo and Serbia a condition for the SAAs (that both countries did aspire). The EU also used the political momentum and made sure it had the international mandate to lead the dialogue. After the International Court of Justice (ICJ) had concluded that Kosovo's declaration of independence 'did not violate

\footnotetext{
${ }^{69} \mathrm{P}$. Feith, Met het Oog op Vrede. de Ervaringen van een Internationale Crisisdiplomaat (Amsterdam: Uitgeverij Balans, 2014): 259.

${ }^{70}$ Ibid., 258.

${ }^{71}$ Radin, 'Analysis of current events', 185-6. An agreement between Kosovo and Serbia on the integrated management of borders eventually mitigated the situation, although the agreed plan of December 2011 was only implemented in December 2012.

${ }^{72}$ A. L. Capussela, The West's state-building policy in Kosovo requires a radical overhaul (no date) http://blogs.Ise.ac.uk/ europpblog/2016/05/05/the-wests-deluded-and-ineffective-policy-in-kosovo-should-change/.

${ }^{73} \mathrm{EEAS}$, 'EU-facilitated Dialogue for the normalisation of relations between Belgrade and Pristina', http://www.eeas. europa.eu/dialogue-pristina-belgrade/index_en.htm See for the General Assembly resolution 64/298, http://www. securitycouncilreport.org/atf/cf/\%7B65BFCF9B-6D27-4E9C-8CD3-CF6E4FF96FF9\%7D/ROL\%20A\%20RES64\%20298.pdf.
} 
international law', High Representative Catherine Ashton declared that the future of Kosovo and Serbia lay in the European Union, and therefore, a dialogue between the two countries should be initiated. The EU's willingness to facilitate the Dialogue was mentioned in the United Nations General Assembly Resolution 64/298 which acknowledged the advisory opinion of the ICJ on Kosovo. ${ }^{74}$

The dialogue led to tangible results. In this section, we focus on the agreement reached on 19 April 2013, in which the two Prime Ministers finally reached the longawaited agreement concerning northern Kosovo. ${ }^{75}$ It was presented as 'The First Agreement of Principles Governing the Normalization of Relations', commonly referred to as the 'April Agreement' or 'the Brussels Agreement'. In 15 points, the agreement covered the governance of the Serb-majority northern Kosovo, where the Kosovo Serbs had continuously refused to accept Pristina's authority. Following the agreement, these municipalities were now to be integrated in the institutional framework of Kosovo. ${ }^{76}$

Indeed, the Brussels Agreement was another 'status neutral' effort to 'normalise relations' between the countries. The Dialogue was portrayed as a technical process, where it was clear to scholars, politicians and EU facilitators that a discussion about such different things as borders, political arrangements and trade would all touch upon the status question in one way or another. This 'hiding' of the political dimension was seen as a strength by EU facilitator Cooper, who - reflecting on the dialogue process called this the 'European method' of seeking peace through practical cooperation. ${ }^{77}$ Others, like Prelec, mockingly referred to the 'Brussels house style' of getting adversaries to commit publicly to an empty agreement 'whose content is to be filled in later, often by EU officials, out of the spotlight'. ${ }^{78}$

A detailed review of the dialogue process shows the sensitivity of the topics under discussion and the difficulties to reach agreement between the countries. ${ }^{79}$ The Dialogue seemed to run aground on various occasions when the differences appeared to be insurmountable. The EU played a very active role in bringing the parties back to the table, suggesting new ways forward, while seemingly never losing its patience. Although for both sides the agreements signed were not easy to defend 'at home', it is fair to say that it was the carrot of EU accession that kept the Dialogue going and eventually led to acceptance of both sides. Moreover, the European External Action Service (EEAS) managed to mobilise international political support for the process. For example, when the talks had to be revived at the end of 2012, Catherine Ashton and Hillary Clinton visited Belgrade and Pristina together, expressing 'the support for Serbia on its EU path', and 'the objection of any kind of talks about Kosovo's borders' ${ }^{80}$

\footnotetext{
${ }^{74}$ General Assembly resolution 64/298, 2, http://www.securitycouncilreport.org/atf/cf/\%7B65BFCF9B-6D27-4E9C-8CD3CF6E4FF96FF9\%7D/ROL\%20A\%20RES64\%20298.pdf.

${ }^{75}$ 'Kosovo and Serbia Reach Historic Deal in Brussels', (13 April 2013) Balkan Insight, http://www.balkaninsight.com/en/ article/kosovo-and-serbia-may-seal-eu-deal.

${ }^{76} \mathrm{~A}$. Beha, 'Disputes Over the 15-Point Agreement on Normalisation of Relations between Kosovo and Serbia', Journal of Nationalism and Ethnicity, 43(1), (2015): 102-21.

${ }^{77}$ R. F. Cooper, 'The Philosophy of the Belgrade-Pristina Dialogue', European Western Balkans (2015), https://european westernbalkans.com/2015/07/16/sir-robert-cooper-the-philosophy-of-the-belgrade-pristina-dialogue/.

${ }^{78} \mathrm{M}$. Prelec, 'The Kosovo-Serbia Agreement: Why Less is More', (2013),

International Crisis Group, http://blog.crisisgroup.org/europe-central-asia/2013/05/07/the-kosovo-serbia-agreement -why-less-is-more/?utm_campaign=shareaholic\&utm_medium=printfriendly\&utm_source=tool.

${ }^{79}$ Van der Borgh et al, EU peacebuilding capabilities in Kosovo, 37-73.
} 
Thus, the EU had a very clear idea of the outcome of the process and coordinated with a limited number of actors that had to be convinced to 'normalise' relations. While the Dialogue shows that the EU is able to facilitate negotiations, leading to increased cooperation between Kosovo and Serbia, it is also fair to say that the practical cooperation was primarily a result of the effectiveness of political pressure of the EU. In this regard, the EU showed its ability to play a 'diplomatic role' in managing to bring parties to the negotiation table that were not really willing to start a dialogue about the normalisation of their relations and the EU strategically used its leverage by linking the Dialogue to its other instruments (most notably the SAA).

But while the EU used its leverage to put pressure on national elites, it left out other stakeholders that had an interest in the process. The communication from the EU about the progress of the Dialogue was minimal, and the political leaders in Kosovo and Serbia were expected to communicate progress and results with their constituencies. The political elites in Serbia, and in Kosovo, had to 'sell' the deal at home. This led to contradictory messages sent out by political elites in Serbia and Kosovo on key issues (such as the nature of the future association in northern Kosovo) and to uncertainty about future developments, especially in the North of Kosovo. ${ }^{81}$

Arguably, these flaws were all part of the difficult process of reaching agreements in a complex and volatile environment and may be seen as a 'price' that had to be paid. However, the different stakeholders involved have different views about the achievement and the price paid for it. Moreover, the dialogue process also led to new fault lines in Kosovo and Serbia between political parties that either resisted or supported the process and agreements. In the North of Kosovo, the agreement intensified the intraethnic split. ${ }^{82}$ In Kosovo, the consequences of the Dialogue for Kosovar statehood were hotly debated in society, leading to escalation in parliament where the opposition used tear gas and laser pointers against the defenders of the deal in the Kosovar parliament. ${ }^{83}$ Another result of the agreement was the growing influence of Belgrade in the North of Kosovo, where the Kosovo Serb leaders disagreed with the deal and the government of Serbia to put together a political party 'Srpska Lista' that operated in line with Belgrade's political stance. ${ }^{84}$

The dialogue between Kosovo and Serbia has further been criticised for a de facto change of strategy of international actors that placed less emphasis on rule of law reform (as promoted by EULEX) and more on hammering out a political deal. Bodo Weber noted that while there was indeed a need 'to put the dialogue first' in order to secure Kosovo's territorial integrity and sovereignty, the EU and the USA 'have underperformed in furthering democratization and the rule of law [and] have been

\footnotetext{
${ }^{80}$ 'Clinton, Ashton Urge Serbia to Continue Kosovo Talks', (30 October 2012) Balkan Insight. http://www.balkaninsight. com/en/article/clinton-ashton-urge-serbia-to-continue-kosovo-talks .

${ }^{81}$ Van der Borgh et al, EU peacebuilding capabilities in Kosovo.

${ }^{82} \mathrm{R}$. Zupančič, 'A Bottom up Perspective on the Normative Power Europe in North Kosovo: the Social Psychological Implications for the Locals', Contemporary Security Policy (2018) (forthcoming).

${ }^{83}$ Kosovo parliament buys scanners to stop MPs bringing teargas to work, The Guardian, 16 March 2016, https://www. theguardian.com/world/2016/mar/11/kosovo-parliament-buys-scanners-to-stop-mps-bringing-teargas-to-work; P. le Roy, Kosovo: a 'European' or an 'Albanian' State? (MA Thesis, Utrecht University, 2016). file:///C:/Users/Chris/ Downloads/MA-thesis-Puck-le-Roy.pdf.

${ }^{84} \mathrm{~N}$. Stel and C. van der Borgh, 'Political parties and minority governance in hybrid political orders: Reflections from Lebanon's Palestinian settlements and Kosovo's Serbian enclaves', in Journal of Intervention and Statebuilding 11, no. 4 (2017), 490-510.
} 
consistently trading democracy and the rule of law to concentrate their efforts on solving the status dispute conflict'. ${ }^{85}$ While this view is not shared by all EU officials, few doubt that tensions exist between different EU interventions and that 'the capability to work in and across different policy domains' was put to the test in the case of Kosovo. It is equally clear that the view of how to work across different policy domains, how to sequence interventions and what a priority is and why was (and often will be) contested. $^{86}$

All in all, the case of the Dialogue shows the EU's ability to play a diplomatic role in managing to bring parties to the negotiation table that were not really willing to start a dialogue about the normalisation of their relations, and the EU strategically used its leverage by linking the Dialogue to its other instruments (most notably the SAA). The EEAS also showed a capability to coordinate with international actors - in particular the USA - at the moment that the Dialogue reached its most difficult moments. But the dialogue process came at the price of excluding large sections of Kosovar and Serbian society. Given the contrasting views and positions about the status of Kosovo at all levels (from the local to the international), a more inclusive dialogue process may sound like a mission impossible, but it seems that the EEAS did not even try to develop more inclusive processes of multi-track diplomacy and seemed to believe that an elite pact was the only viable option. This choice came at the price of a lack of transparency and lacking popular support for the deal.

\section{Conclusion}

This paper analysed the capability to coordinate of the EU in two important interventions in Kosovo in the period after 2008. Particular attention was given to the capability - context nexus and the ways in which the EU interacted with a range of national and international actors. Intervention is conceived as a political process in which there is no pre-existing consensus about outcomes and actors need to construct a basis for collective action - a process that often involves intense negotiations. ${ }^{87}$ The paper showed that tensions exist within EU Member States, between EU agencies, between the EU and other international actors and with local actors (national and subnational elites, civil society and citizens at large). Especially, the ongoing contestation about Kosovo's status at different levels (from the international to the local level) has greatly hampered the possibilities of the EU to coordinate different actors. However, the EU dealt differently with this challenge in the two interventions studied in this paper.

A major critique on the EULEX intervention has been that it was largely ineffective in terms of addressing organised crime and corruption. The complex international and national context in which EULEX deployed was certainly not helpful in this regard, but the claim of the ECA report that the 'special circumstances' cannot account for all the problems seems fair. The political nature of the task at hand was insufficiently recognised by EULEX. Not only had the mission to navigate between actors that held opposing views about the status of Kosovo, it also had to coordinate with the very

\footnotetext{
${ }^{85}$ B. Weber, Progress Undone? Trading Democracy for Solving the Status Dispute in Kosovo (Berlin: DPC, 2015), i.

${ }^{86}$ Whitman and Wolff, The European Union, 11.

${ }^{87}$ Colebatch, Policy, 26.
} 
national political elites that were involved in organised crime and in corruption. EULEX' contacts and interactions with civil society could not compensate for this. Breaking the power of national elites would have required a clearer strategy of the EU and a coalition capable to implement that strategy. This would also imply a more explicit choice to include some actors and to exclude others in what Whitman and Wolff call 'a broad coalition [...] in support of an outcome-oriented process'. However, such a strategy would require a more intrusive role of the EU and would very likely come at the price of local stability - at least in the short term. The EU was not able to forge such a coalition, and if it would have been able, the question is whether it would not have been willing to pay the price of instability.

Interestingly, the EU-facilitated Dialogue had a much clearer objective (normalisation of the relations between Serbia and Kosovo) and a clear strategy how to achieve this. While both Serbian and Kosovar leaders were not keen to start a new round of dialogue and kept emphasising that they were not willing to change their positions about the status of Kosovo, it is fair to say that the EU pushed, if not forced, the two countries to join the Dialogue. The EU was quite successful in using the 'momentum' (the ICJ's opinion regarding Kosovo's independence), while the carrot of EU accession kept the Dialogue going and eventually led to acceptance of both sides. The EU played a proactive role in this process. It pushed the Kosovar and Serbian governments to reach agreements about the relations between the countries (without addressing the status issue). This was a highly 'exclusive' process with no involvement of civil society from Kosovo (including the North) and Serbia. However, this could not prevent that the process led to political turmoil in Kosovo and to political rearrangements in the northern part of Kosovo.

While it is understandable that international actors did not place emphasis on a more inclusive approach, from a WoS perspective, the question whether a broader involvement of local actors would have been possible is highly relevant. It would be too simplistic to argue that the inclusion of more stakeholders will lead to better results and that a WoS approach will be able to bring together the divergent interests of different stakeholders. However, a WoS reminds us of the need to involve a broader range of local actors, while recognising that inclusion brings new challenges. The opportunities and challenges of such an approach will always depend on the local context. But it seems fair to say that the EU failed to fully understand that local context and that a WoS approach would have led it to perform a more rigorous and dynamic evaluation of local society, identifying relevant stakeholders and matching these with its ambitions in different policy domains.

When it comes to rule of law reform, simply 'involving civil society' is not enough, and a combination of clear strategy and selective inclusion would be needed. International actors should recognise the deeply political nature of the reform process and the normative agenda that this entails. Corruption is a particularly interesting example of how a thicker engagement with different stakeholders (building a coalition with selected local actors willing to push for reforms) and an understanding of local processes could provide the EU with a more effective response. In the case of the Dialogue - an 'all exclusive' process, involvement of other stakeholders at different levels might have slowed down the 
process and would require certain skills of the facilitators. In a deeply politicised environment there is no guarantee to success, but greater involvement of local actors might have led to more support for the agreements and more sustainable outcome of the process.

\section{Notes on contributors}

Chris van der Borgh (PhD), is a lecturer, researcher and consultant with the Centre for Conflict Studies at Utrecht University. He specialises in issues of peace and security, political order and international intervention. Recent publications focus on the politics of security provision in Kosovo and El Salvador.

Puck le Roy (MA), received a Master's degree in Conflict Studies and Human Rights at Utrecht University and a Diplôme des Hautes Études in European and International Studies at the Centre International de Formation Européenne (CIFE) in cooperation with the University of Kent. She currently works at the Dutch Embassy in Berlin.

Floor Zweerink (MA), took the Master Conflict Studies and Human Rights at Utrecht University, and was junior researcher at the Centre for Conflict Studies at Utrecht University. She currently works for the Dutch government as researcher in the field of international security. 